\title{
$n$-Alkan-2-ones in peat-forming plants from the Roñanzas ombrotrophic bog (Asturias, northern Spain)
}

\author{
José E. Ortizz,*, Arantxa Díaz-Bautista ${ }^{a}$, Juan José Aldasoro ${ }^{\mathrm{b}}$, Trinidad Torres ${ }^{\mathrm{a}}$, José Luis R. Gallego ${ }^{\mathrm{c}}$, \\ Laura Moreno ${ }^{\mathrm{a}}$, Belén Estébanez ${ }^{\mathrm{d}}$ \\ ${ }^{a}$ Biomolecular Stratigraphy Laboratory, E.T.S.I. Minas, Universidad Politécnica de Madrid, C/Ríos Rosas 21 - 28003 Madrid, Spain \\ ${ }^{\mathrm{b}}$ Real Jardín Botánico de Madrid, Plaza de Murillo 2 - 28014 Madrid, Spain \\ ${ }^{\complement}$ Environmental Biotechnology and Geochemistry Group. Campus de Mieres, Universidad de Oviedo, C/Gonzalo G, s/n - 33600 Mieres, Asturias, Spain \\ ${ }^{\mathrm{d}}$ Facultad de Ciencias (Biología), Universidad Autónoma de Madrid, Campus de Cantoblanco, C/Darwin 2 - 28049 Madrid, Spain
}

\begin{abstract}
A B S T R A C T
We determined the distribution of lipids ( $n$-alkanes and $n$-alkan-2-ones) in present-day peat-forming plants in the Roñanzas Bog in northern Spain. Consistent with the observation of others, most Sphagnum (moss) species alkanes maximized at $\mathrm{C}_{23}$, whereas the other plants maximized at higher molecular weight $\left(C_{27}\right.$ to $\left.C_{31}\right)$. We show for the first time that plants other than seagrass and Sphagnum moss contain $n$-alkan-2-ones. Almost all the species analysed showed an $n$-alkan-2-one distribution between $C_{21}$ and $C_{31}$ with an odd/even predominance, maximizing at $C_{27}$ or $C_{29}$, except ferns, which maximized at lower molecular weight $\left(\mathrm{C}_{21}-\mathrm{C}_{23}\right)$. We also observed that microbial degradation can be a major contributor to the $n$-alkan-2-one distribution in sediments as opposed to a direct input of ketones from plants.
\end{abstract}

\section{Introduction}

Biomarkers such as $n$-alkanes and $n$-alkan-2-ones are widely observed in peat samples from ombrotrophic mires. There is extensive literature about the significance of $n$-alkanes and the profile of these lipids has been used to discriminate Sphagnum vs. non-Sphagnum inputs and, furthermore, to interpret palaeoenvironmental conditions linked to humid or drier climatic phases (Nott et al., 2000; Pancost et al., 2002; Avsejs et al., 2002; McClymont et al., 2005; Nichols et al., 2006; Ortiz et al., 2010).

$n$-Alkan-2-ones also occur in peat (Morrison and Bick, 1967; Lehtonen and Ketola, 1990,1993 Xie et al., 2004; Nichols and Huang, 2007; Zheng et al., 2007; Ortiz et al., 2010), but less is known about their significance. In addition to their direct provenance from plants (Arpino et al., 1970; Volkman et al., 1981), long chain ketones may have other origins, including microbial oxidation of the corresponding $n$-alkanes (Cranwell et al., 1987; Amblès et al., 1993; Jaffé et al., 1993, 1996; van Bergen et al., 1998) or microbial $\beta$-oxidation and decarboxylation of $n$-fatty acids (Volkman et al., 1983; Chaffee et al., 1986; de Leeuw, 1986; Quénéa et al., 2004). These origins are particularly relevant to peat bogs, which can register considerable microbial activity (cf. Lehtonen and Ketola, 1990; Zheng et al., 2007).

Thus, although $n$-alkan-2-ones have been addressed extensively in various kinds of sediments, most studies have focussed mainly on their distribution and origin, and assessments of their use as palaeoclimate proxies in sediments remain scarce (Xie et al., 2003,2008 ) in comparison with other $n$-alkyl lipids. Furthermore, only a few studies show the $n$-alkan-2-one distribution in modern plants, with $C_{17}$ to $C_{33}$ components being observed in cyanobacteria and aquatic macrophytes (Wenchuan et al., 1999), as well as seagrass (Hernández et al., 2001) and Sphagnum species (Baas et al., 2000; Nichols and Huang, 2007). $C_{25}$ to $C_{31}$ n-alkan-2-ones have also been reported in measurable but very low concentrations in forest and paramo plant species in the Northern Ecuadorian Andes (Jansen and Nierop, 2009).

Here we address the distribution of $n$-alkanes and n-alkan-2 ones in diverse peat-forming plants collected from the Roñanzas ombrotrophic bog (Asturias, northern Spain) and discuss their possible microbial origin.

\section{Methodology}

Field specimens of the plants (Table 1 ) were collected in mid September 2009 from the Roñanzas bog $\left(43^{\circ} 20^{\prime} 13^{\prime \prime} \mathrm{N}\right.$; $04^{\circ} 51^{\prime} 01^{\prime \prime} \mathrm{W} ; 250 \mathrm{~m}$ ), which covers ca. $80,000 \mathrm{~m}^{2}$. In most cases leaves were selected, although for others, both leaves and stems or flowers were analysed. Five Sphagnum species were sampled (three of them different from those examined by Baas et al. (2000) and Nichols and Huang (2007): Sphagmum subnitens, Sphagnum subsecundum and Sphagnum denticulatum) together with two non-Sphagnum mosses (Campylopus pyriformis and Campylopus 
Table 1

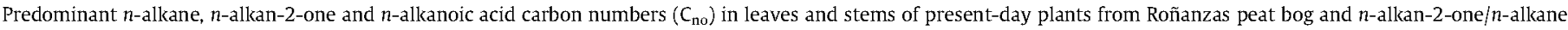
ratio.

\begin{tabular}{|c|c|c|c|c|c|}
\hline Name & Common name & $n$-Alkane $\mathrm{C}_{\text {no }}$ & n-Alkan-2-one $C_{\text {no }}$ & $n$-Alkanoic $C_{\text {no }}$ & n-Alkan-2-one/n-alkane \\
\hline Calluna vulgaris (leaves) & Scotch heather & 31 & 29 & 24 & 0.009 \\
\hline Calluna vulgaris (stem) & Scotch heather & 29 & 27 & 24 & 0.200 \\
\hline Campylopus introflexus & Moss & 27 & 27 & 24 & 0.078 \\
\hline Campylopus pyriformis & Moss & 29 & 27 & 24 & 0.131 \\
\hline Carex canescens & Silvery sedge & 27 & 29 & 24 & 0.059 \\
\hline Drosera intermedia & Spoonleaf sundew & 27 & 27 & 24 & 0.044 \\
\hline Erica mackaiana (leaves) & Mackay's heather & 31 & 27 & 28 & 0.009 \\
\hline Erica mackaiana (stem) & Mackay's heather & 31 & 27 & 22 & 0.051 \\
\hline Juncus articulatus & Jointleaf rush & 31 & 31 & 24 & 0.008 \\
\hline Juncus effusus (flowers) & Soft rush & 23 & 27 & 22 & 0.031 \\
\hline Juncus effusus (stem) & Soft rush & 29 & 29 & 24 & 0.075 \\
\hline Molinia caerulea & Purple moor grass & 29 & 27 & 26 & 0.037 \\
\hline Molinia sp. & Grass & 31 & 31 & 24 & 0.040 \\
\hline Osmunda regalis & Fern & 31 & - & 30 & - \\
\hline Pteridium aquilinum (leaves) & Fern & 27 & 21 & 24 & 0.038 \\
\hline Pteridium aquilinum (stem) & Fern & 27 & 23 & 24 & 0.016 \\
\hline Rhynchospora alba & White beaksedge & 31 & 29 & 22 & 0.019 \\
\hline Sphagmum compactum & Sphagnum moss & 23 & 27 & 24 & 0.148 \\
\hline Sphagmum cuspidatum & Sphagnum moss & 31 & 27 & 24 & 0.089 \\
\hline Sphagmum denticulatum & Sphagnum moss & 23 & 27 & 24 & 0.132 \\
\hline Sphagmum subnitens & Sphagnum moss & 23 & 27 & 24 & 0.151 \\
\hline Sphagnum subsecundum & Sphagnum moss & 25 & 27 & 24 & 0.193 \\
\hline Ulex europaeus (leaves) & Gorse & 29 & 27 & 22 & 0.017 \\
\hline Ulex europaeus (stem) & Gorse & 27 & 27 & 22 & 0.053 \\
\hline
\end{tabular}

introflexus), two Ericaceae species, ferns and some other plant types (Table 1).

In order to avoid degradation and contamination, samples were stored frozen until analysis 2-3 days after collection. They were then washed independently with distilled deionized water, classified and analysed following the same procedure as peat samples taken along the $2 \mathrm{~m}$ deep record for palaeoenvironmental reconstruction during the last $8 \mathrm{cal} \mathrm{ka} \mathrm{B.P.} \mathrm{(cf.} \mathrm{Ortiz} \mathrm{et} \mathrm{al.,} \mathrm{2010).} \mathrm{To} \mathrm{pre-}$ vent contamination between samples (e.g. waxes ejected to the air that might attach to other plants), we worked with only one sample from opening the bag until putting the sample into the cell for extraction.

Samples were extracted using an accelerated solvent extractor (Dionex ASE 200) with dichloromethane (DCM)/MeOH (2:1) at $1500 \mathrm{psi}$ and $175^{\circ} \mathrm{C}$. The heating phase was $8 \mathrm{~min}$ and the static extraction time $5 \mathrm{~min}$.

The extract was concentrated using a rotary evaporator. Three fractions, $A, B$ and $C$ respectively, were obtained by passing the extract through a silica/alumina column ( $14.2 \mathrm{~g}$ silica, $7.7 \mathrm{~g}$ alumina; $70-230 \mathrm{~mm}$ mesh) and washing it using solvents of different polarity $(80 \mathrm{ml}$ in all cases): hexane $(A), D C M /$ hexane $(4: 1, B)$ and $\mathrm{MeOH}(\mathrm{C})$ to afford neutral, polar and acid fractions. Prior to analysis, fractions were methlylated with trimethylsilyldiazomethane and $\mathrm{MeOH}$ for $20 \mathrm{~min}$ and the solvent evaporated with $\mathrm{N}_{2}$. Only fractions $A$ and $B$ were analysed. Samples were injected into an HP 6890 gas chromatograph equipped with a selective mass detector (HP 5973) and an ATM-5 column ( $25 \mathrm{~m} \times 0.25 \mathrm{~mm}$; $0.20 \mu \mathrm{m}$ ). We used He as carrier gas and decafluorobiphenyl as internal standard. The oven temperature programme was: $60-300^{\circ} \mathrm{C}$ (held $20 \mathrm{~min}$ ) at $6^{\circ} \mathrm{C} / \mathrm{min}$ and the injector was maintained at $275^{\circ} \mathrm{C}$. Components were identified with the Data Analysis programme and the Wiley Library; $n$-alkane distributions were obtained using the base peak chromatograms for fraction $A$, the $m / z 59$ chromatograms for the $n$-alkan-2-ones in fraction $B$ and the $m / z 74$ chromatograms for the $n$-alkanoic acids in fraction $B$. For quantification, we used the internal standard for each sample and some $n$-alkane standards at different concentrations, which were analysed before and after the injection of the plant samples.

\section{Results and discussion}

The leaves and stems of Sphagnum and Ericaceae species comprise the main plant input to the Roñanzas peat bog, although other plants also influenced peat composition. For almost all Sphagnum spp., the $n$-alkanes maximized at $C_{23}$, except $S$. subsecundum (bimodal at $C_{25}$ and $C_{29}$ ) and $S$. cuspidatum, (bimodal at $C_{23}$ and $C_{29}$ ). The other plants exhibited a greater predominance of higher molecular weight (HMW) $n$-alkanes, mainly at $C_{29}$ and $C_{31}$ (Tables 1 and 2). These results coincide with previous studies (Baas et al., 2000; Nott et al., 2000; Pancost et al., 2002; Nichols et al., 2006) showing that the predominant $n$-alkane in Sphagnum is $C_{23}$, while $C_{31}$ is the most abundant in other plants.

In most cases the $n$-alkan-2-ones ranged from $C_{21}$ to $C_{31}$, with an odd/even predominance (Table 3 ; Fig. 1 ). Only for the fern Osmunda regalis were no ketones detected. The $n$-alkan-2-ones in Sphagnum spp. maximized at $\mathrm{C}_{27}$, like Ericaceae species and other plants, in which the $C_{29}$ homologue was also predominant. Only the fern Pteridium aquilinum ketones maximized at $C_{21}$ or $C_{23}$.

These results coincide with the findings of previous studies (Baas et al., 2000; Nichols and Huang, 2007), in which long chain odd $n$-alkan-2-ones between $C_{23}$ and $C_{31}$ were observed in all species of Sphagnum, maximizing at $C_{27}$. However, other common plant species in bogs also contain $n$-alkan-2-ones differing from those in Sphagnum spp. (Nichols and Huang, 2007), so these compounds cannot be considered exclusive biomarkers for the genus Sphagnum in freshwater peatlands. Our study included other non-Sphagnum species than those examined by Nichols and Huang (2007) in North America; only one genus (Carex) is common to both studies. In our view, the different species addressed in these two studies would explain why we observed the presence of $n$-alkan-2-ones in species other than Sphagnum and they did not. In fact, it is noticeable that we did not detect n-alkan-2-ones in one fern (O. regalis), whereas in leaves and stems of the other fern species (P. aquilinum) they were present (Table 2). Another explanation would be because the North American plants analysed in Nichols and Huang (2007) had ketones, but not in detectable amounts. 
Table 2

Concentration (n.d. - not detected) of n-alkanes in leaves and stems of plants from Roñanzas peat bog (highest values in bold).

\begin{tabular}{|c|c|c|c|c|c|c|c|c|c|c|c|c|c|c|c|c|c|c|}
\hline \multirow[t]{2}{*}{ Species } & \multicolumn{18}{|c|}{ Alkane $C_{\text {no }}(\mu g / g$ dry plant matter $)$} \\
\hline & 17 & 18 & 19 & 20 & 21 & 22 & 23 & 24 & 25 & 26 & 27 & 28 & 29 & 30 & 31 & 32 & 33 & Sum \\
\hline Calluna vulgaris (leaves) & 0.00 & 0.39 & 4.00 & 0.91 & 38.98 & 1.65 & 8.51 & 1.42 & 16.87 & 4.72 & 84.06 & 9.64 & 51.85 & 10.90 & 186.53 & 13.59 & 99.36 & 533.38 \\
\hline Calluna vulgaris (stem) & 0.19 & 0.18 & 0.47 & 0.46 & 2.18 & 1.16 & 3.95 & 1.03 & 4.12 & 1.33 & 11.32 & 1.92 & 6.84 & 0.88 & 5.23 & 0.14 & 0.83 & 42.23 \\
\hline Campylopus introflexus & 0.42 & 0.07 & 0.52 & 0.19 & 0.93 & 1.37 & 0.29 & 0.20 & 0.61 & 0.22 & 4.75 & 0.63 & 4.28 & 0.46 & 4.96 & 0.31 & 0.81 & 21.02 \\
\hline Campylopus pyriformis & 0.16 & 0.11 & 0.23 & 0.19 & 1.37 & 1.12 & 0.65 & 0.32 & 1.16 & 0.31 & 2.38 & 0.76 & 4.16 & 0.36 & 3.30 & 0.22 & 0.34 & 17.14 \\
\hline Carex Canescens & 0.45 & 0.20 & 0.91 & 0.22 & 1.71 & 0.70 & 3.72 & 0.99 & 6.37 & 1.27 & 9.29 & 1.17 & 6.98 & 0.59 & 3.07 & 0.10 & 0.76 & 38.50 \\
\hline Drosera intermedia & 0.59 & 0.36 & 3.57 & 0.98 & 2.80 & 0.73 & 5.18 & 1.42 & 11.95 & 1.86 & 22.15 & 4.70 & 20.73 & 1.84 & 6.12 & 0.46 & 0.74 & 86.18 \\
\hline Erica mackaiana (leaves) & 0.00 & 0.00 & 0.88 & 28.01 & 0.64 & 1.03 & 11.59 & 1.20 & 15.34 & 1.10 & 23.15 & 2.11 & 22.29 & 2.48 & 41.61 & 2.07 & 13.59 & 167.09 \\
\hline Erica mackaiana (stem) & 0.00 & 0.00 & 3.02 & 1.38 & 6.95 & 2.46 & 3.10 & 2.13 & 6.18 & 2.37 & 27.89 & 4.52 & 17.23 & 2.51 & 29.24 & 0.79 & 3.90 & 113.67 \\
\hline Juncus articulatus & 0.07 & 0.26 & 0.44 & 0.13 & 1.66 & 0.24 & 1.09 & 0.26 & 1.52 & 0.26 & 2.77 & 0.55 & 13.58 & 1.21 & $\mathbf{3 1 . 7 7}$ & 1.64 & 32.40 & 89.85 \\
\hline Juncus effusus (flowers) & 0.24 & 0.14 & 1.89 & 0.31 & 3.68 & 1.00 & 13.04 & 2.66 & 14.29 & 2.20 & 13.03 & 2.50 & 12.07 & 0.98 & 2.66 & 0.11 & 1.84 & 72.64 \\
\hline Juncus effusus (stem) & 0.00 & 0.06 & 0.58 & 0.05 & 1.05 & 0.19 & 0.29 & 0.07 & 0.43 & 0.13 & 0.63 & 1.52 & 3.38 & 0.61 & 0.92 & 0.04 & 1.00 & 10.95 \\
\hline Molinia caerulea & 0.47 & 0.66 & 1.27 & 0.49 & 2.67 & 1.26 & 1.46 & 1.02 & 4.79 & 1.29 & 9.79 & 2.56 & 94.67 & 0.77 & 3.70 & 0.45 & 0.48 & 127.80 \\
\hline Molinia sp. & 0.07 & 0.09 & 0.19 & 0.14 & 0.48 & 0.21 & 1.04 & 0.40 & 2.52 & 0.88 & 3.81 & 3.38 & 11.68 & 1.19 & 13.73 & 0.18 & 0.74 & 40.73 \\
\hline Osmunda regalis & 0.58 & 1.83 & 1.91 & 0.25 & 3.07 & 0.69 & 1.77 & 0.64 & 3.01 & 0.61 & 32.16 & 2.17 & 28.70 & 1.49 & 91.91 & 3.92 & 4.39 & 179.10 \\
\hline Pterudium aquilinum & 0.00 & 0.00 & 0.00 & 0.00 & 2.37 & 0.19 & 0.68 & 0.13 & 1.43 & 0.20 & 3.54 & 0.31 & 2.21 & 0.13 & 0.61 & 0.00 & 0.00 & 11.80 \\
\hline Pterudium aquilinum & 0.00 & 0.00 & 4.92 & 0.34 & 1.26 & 0.14 & 0.38 & 0.02 & 0.76 & 0.11 & 1.76 & 0.36 & 1.06 & 0.09 & 0.29 & 0.03 & 1.13 & 12.65 \\
\hline Rhynchospora alba & 0.17 & 0.69 & 1.44 & 0.59 & 4.26 & 0.77 & 5.22 & 1.09 & 5.30 & 0.67 & 6.85 & 1.29 & 19.62 & 1.35 & 15.84 & 0.24 & 1.05 & 66.44 \\
\hline Sphagnum compactum & 0.00 & 0.00 & 0.22 & 0.24 & 5.45 & 1.35 & 21.04 & 1.22 & 10.58 & 0.52 & 12.19 & 1.59 & 8.09 & 0.83 & 7.37 & 1.04 & 0.63 & 72.36 \\
\hline Sphagnum cuspidatum & 2.51 & 0.31 & 0.99 & 0.95 & 0.81 & 0.98 & 6.68 & 1.70 & 3.93 & 0.59 & 6.50 & 1.61 & 6.84 & 2.45 & 17.45 & 1.45 & 0.88 & 56.63 \\
\hline Sphagnum denticulatum & 0.00 & 0.28 & 0.76 & 0.26 & 5.82 & 1.14 & 12.09 & 1.34 & 4.90 & 0.45 & 3.09 & 1.09 & 3.59 & 0.58 & 1.88 & 0.27 & 0.34 & 37.88 \\
\hline Sphagnum subnitens & 0.52 & 0.12 & 0.32 & 0.29 & 3.39 & 1.09 & 11.84 & 1.21 & 4.16 & 0.49 & 4.56 & 1.27 & 5.53 & 0.51 & 4.14 & 0.59 & 0.12 & 40.15 \\
\hline Sphagnum subsecundum & 0.00 & 0.20 & 0.26 & 19.26 & 2.12 & 0.75 & 7.39 & 1.14 & 9.19 & 0.69 & 2.46 & 1.96 & 7.40 & 0.94 & 2.26 & 0.36 & 0.44 & 56.82 \\
\hline Ulex europaeus (leaves) & 0.00 & 0.00 & 0.00 & 0.14 & 3.23 & 0.84 & 7.51 & 1.25 & 5.31 & 1.14 & 12.35 & 3.59 & 21.31 & 3.94 & 19.80 & 0.23 & 1.23 & 81.87 \\
\hline Ulex europaeus (stem) & 0.03 & 0.04 & 0.17 & 2.25 & 0.30 & 0.06 & 0.28 & 0.06 & 1.25 & 0.23 & 1.65 & 0.29 & 0.85 & 0.15 & 0.83 & 0.10 & 0.21 & 8.75 \\
\hline
\end{tabular}

Table 3

Concentration (n.d. - not detected) of n-alkan-2-ones in leaves and stems of plants from Roñanzas peat bog (highest values in bold).

\begin{tabular}{|c|c|c|c|c|c|c|c|c|c|c|c|c|}
\hline \multirow[t]{2}{*}{ Name } & \multicolumn{12}{|c|}{ Alkan-2-one $C_{\text {no }}(\mu \mathrm{g} / \mathrm{g}$ dry plant matter) } \\
\hline & 21 & 22 & 23 & 24 & 25 & 26 & 27 & 28 & 29 & 30 & 31 & Sum \\
\hline Calluna vulgaris (leaves) & 0.40 & 0.54 & 0.58 & 0.30 & 0.53 & 0.28 & 0.76 & 0.11 & 0.80 & 0.06 & 0.30 & 4.66 \\
\hline Calluna vulgaris (stem) & 0.25 & 0.13 & 0.55 & 0.24 & 2.02 & 0.29 & 2.37 & 0.30 & 1.99 & 0.10 & 0.18 & 8.42 \\
\hline Campylopus introflexus & 0.04 & 0.08 & 0.13 & 0.04 & 0.31 & 0.07 & 0.53 & 0.06 & 0.27 & 0.05 & 0.07 & 1.65 \\
\hline Campylopus pyriformis & 0.11 & 0.03 & 0.14 & 0.05 & 0.63 & 0.13 & 0.90 & 0.05 & 0.20 & 0.02 & 0.05 & 2.31 \\
\hline Carex canescens & 0.11 & 0.06 & 0.25 & 0.20 & 0.34 & 0.06 & 0.41 & 0.07 & 0.42 & 0.06 & 0.32 & 2.30 \\
\hline Drosera intermedia & 0.24 & 0.05 & 0.38 & 0.18 & 0.83 & 0.22 & 0.87 & 0.11 & 0.38 & 0.33 & 0.18 & 3.77 \\
\hline Erica mackaiana (leaves) & 0.34 & 0.09 & 0.15 & 0.02 & 0.24 & 0.04 & 0.36 & 0.04 & 0.21 & 0.02 & 0.01 & 1.52 \\
\hline Erica mackaiana (stem) & 0.11 & 0.01 & 0.14 & 0.05 & 0.48 & 0.15 & 2.27 & 0.15 & 2.02 & 0.15 & 0.30 & 5.83 \\
\hline Juncus articulatus & 0.01 & 0.00 & 0.06 & 0.02 & 0.07 & 0.01 & 0.12 & 0.01 & 0.15 & 0.02 & 0.28 & 0.75 \\
\hline Juncus effusus (flowers) & 0.05 & 0.03 & 0.17 & 0.03 & 0.16 & 0.04 & 0.37 & 0.09 & 0.84 & 0.09 & 0.37 & 2.24 \\
\hline Juncus effusus (stem) & 0.05 & 0.02 & 0.04 & 0.01 & 0.10 & 0.02 & 0.13 & 0.04 & 0.21 & 0.02 & 0.17 & 0.81 \\
\hline Molinia caerulea & 0.12 & 0.11 & 0.34 & 0.26 & 0.65 & 0.57 & 1.62 & 0.07 & 0.59 & 0.150 & 0.19 & 4.67 \\
\hline Molinia sp. & 0.03 & 0.02 & 0.10 & 0.04 & 0.15 & 0.04 & 0.21 & 0.06 & 0.33 & 0.03 & 0.61 & 1.62 \\
\hline Osmunda regalis & n.d. & n.d. & n.d. & n.d. & n.d. & n.d. & n.d. & n.d. & n.d. & n.d. & n.d. & 0.00 \\
\hline Pteridium aquilinum (leaves) & 0.13 & 0.00 & 0.11 & 0.03 & 0.10 & 0.01 & 0.03 & 0.01 & 0.02 & n.d. & n.d. & 0.44 \\
\hline Pteridium aquilinum (stem) & 0.02 & 0.01 & 0.05 & 0.01 & 0.04 & 0.01 & 0.03 & 0.01 & 0.03 & n.d. & n.d. & 0.21 \\
\hline Rhynchospora alba & 0.04 & 0.03 & 0.13 & 0.04 & 0.12 & 0.02 & 0.21 & 0.02 & 0.36 & 0.02 & 0.28 & 1.27 \\
\hline Sphagnum compactum & 0.04 & 0.31 & 0.26 & 0.12 & 2.71 & 0.66 & 5.59 & 0.23 & 0.57 & 0.05 & 0.20 & 10.74 \\
\hline Sphagmum cuspidatum & 0.57 & 0.16 & 0.32 & 0.18 & 0.92 & 0.44 & 2.72 & 0.64 & 0.77 & 0.11 & 0.23 & 7.06 \\
\hline Sphagmum denticulatum & 0.05 & 0.07 & 0.14 & 0.07 & 0.63 & 0.41 & 2.87 & 0.26 & 0.36 & 0.03 & 0.09 & 4.98 \\
\hline Sphagnum subnitens & 0.08 & 0.13 & 0.25 & 0.12 & 0.85 & 0.53 & 3.12 & 0.35 & 0.46 & 0.04 & 0.14 & 6.07 \\
\hline Sphagnum subsecundum & 0.08 & 0.05 & 0.19 & 0.02 & 1.72 & 0.61 & 6.89 & 0.38 & 0.73 & 0.05 & 0.17 & 10.89 \\
\hline Ulex europaeus (leaves) & 0.07 & 0.05 & 0.13 & 0.02 & 0.05 & 0.05 & $\mathbf{0 . 3 1}$ & 0.06 & 0.26 & 0.09 & 0.29 & 1.38 \\
\hline Ulex europaeus (stem) & 0.07 & 0.01 & 0.03 & 0.01 & 0.06 & 0.02 & 0.12 & 0.01 & 0.06 & 0.01 & 0.04 & 0.44 \\
\hline
\end{tabular}

The different methodology used in Nichols and Huang (2007) for the lipid extraction and/or the sensitivity of the gas chromatography-mass spectrometry (GC-MS) method employed might be another reason to explain these differences, but the n-alkan-2one distributions and abundances of Sphagnum mosses in North America (Nichols and Huang, 2007) coincide with our results. In our view, the fact that both studies were performed in different areas is not a major reason as the $n$-alkane patterns in Sphagnum and non-Sphagnum species found in Roñanzas are similar to those in several peat bogs in The Netherlands and Ireland (Baas et al., 2000; Pancost et al., 2002), United Kingdom (Nott et al., 2000) and USA (Nichols et al., 2006).
The concentration of $n$-alkan-2-ones was not very high when compared with $n$-alkanes (Tables 2 and 3 ). In fact, the $n$-alkan-2one $/ n$-alkane ratio (calculated as the sum of the concentration of $n$-alkan-2-ones relative to the sum of the concentration of $n$-alkanes) in presentday plants from Roñanzas ranged between 0.009 and 0.200 (Table 1). Notwithstanding, Baas et al. (2000) also observed that Sphagnum spp. contained only relatively small amounts of $C_{25}$ and $C_{27}$ n-alkan-2-ones. Similarly this, in a number of forest and paramo species, Jansen and Nierop (2009) found small concentrations of $n$-alkan-2-ones in the same range as roots of several species and leaves from one species as those detected in the plants addressed in our study. Also, the abundances of $n$-alkan-2-ones in 
Abundance

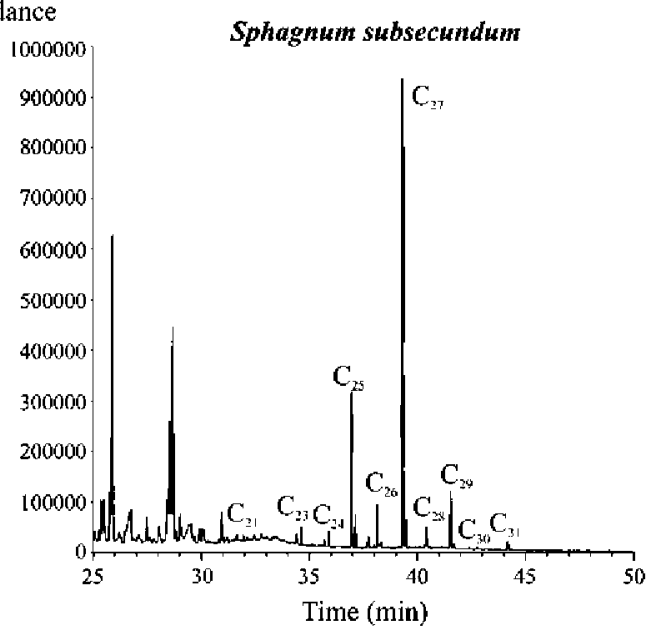

Abundance

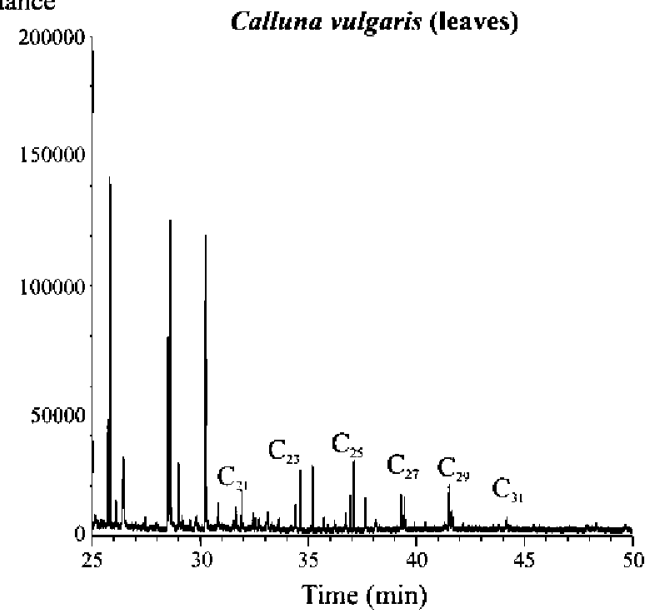

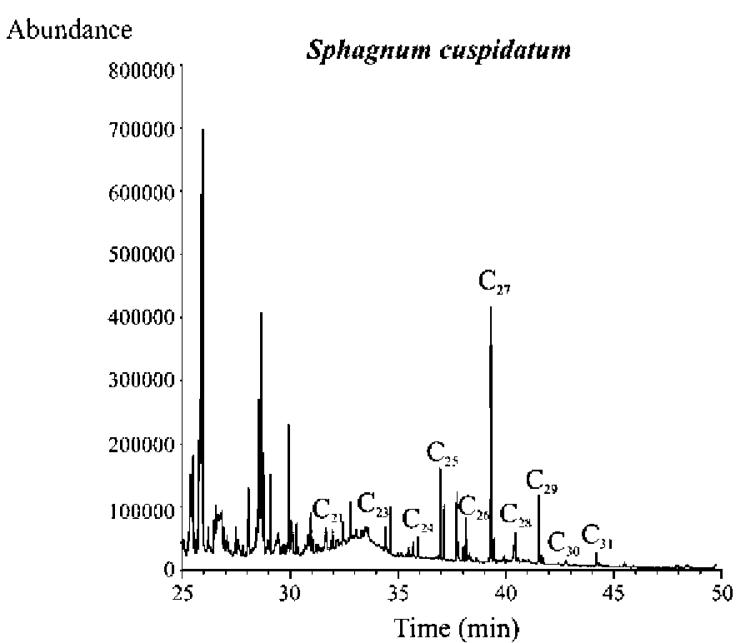

Abundance $\quad$ Erica mackaiana (stem)

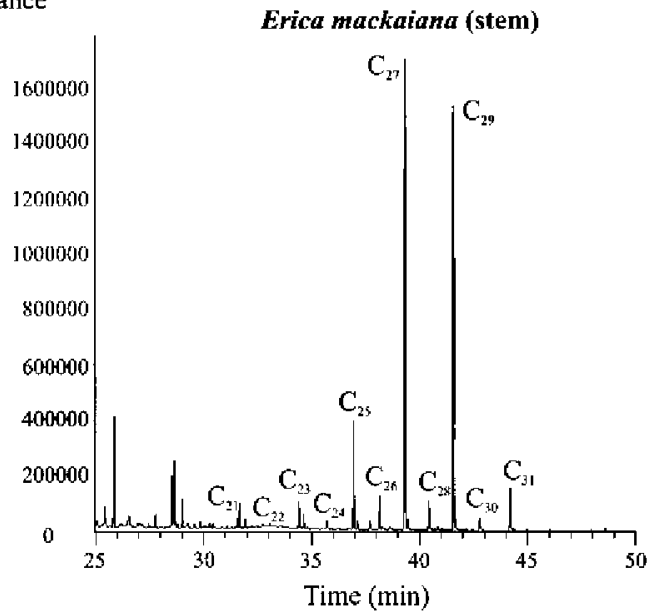

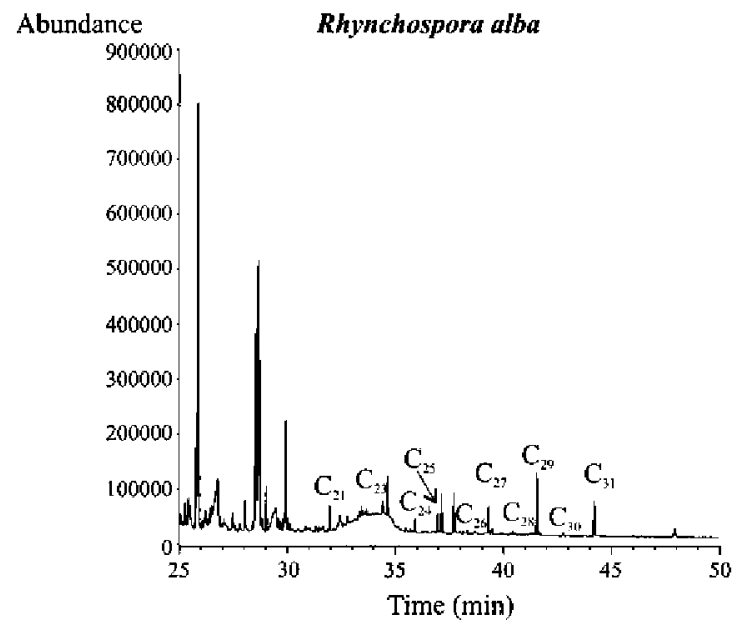

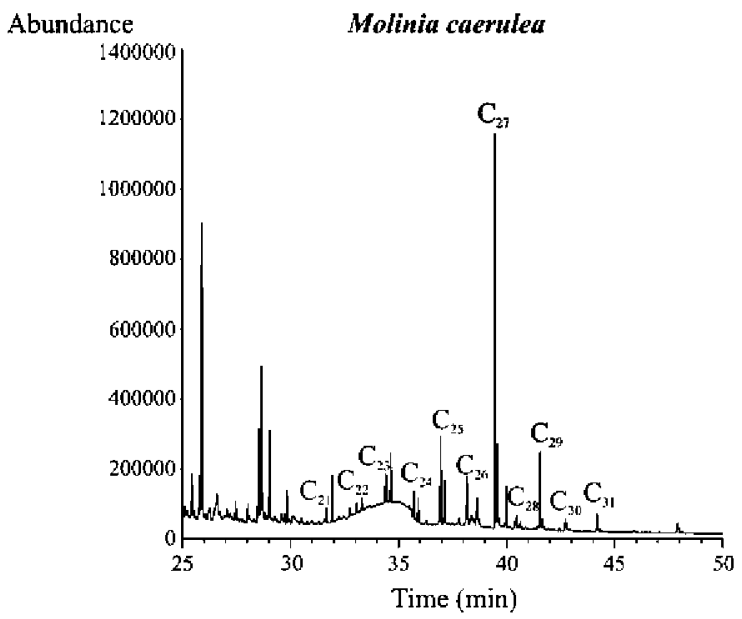

Fig. 1. Distribution of $n$-alkan-2-ones in (a) Sphagnum subsecundum (moss), (b) Sphagnum cuspidatum (moss), (c) Calluna vulgaris (Scotch heather), (d) Erica mackaiana (Mackay's heather), (e) Rhynchospora alba (white beaksedge) and (f) Molinia caerulea (purple moor grass).

the Sphagnum spp. (Table 3) do not differ to those reported by Nichols and Huang (2007) for other species of this genus.

In general, Sphagnum spp. showed a higher concentration of n-alkan-2-ones than other plants (Table 3), except the Ericaceae species (Calluna vulgaris and Erica mackaiana). These represent the other main components of ombrotrophic bogs and are commonly used for discriminating between more humid episodes (in which Sphagnum spp. dominate) and drier periods (with predominating Ericaceae spp.; cf. Nott et al., 2000; Avsejs et al., 2002; Pancost et al., 2002; McClymont et al., 2005; Nichols et al., 2006; Ortiz et al., 2010). Of note, the stems of the heathers $C$. vulgaris and E. mackaiana contained higher concentrations of $n$-alkan-2-ones than their leaves, whereas, for Ulex europaeus, the opposite was apparent (Table 3 ). 


\subsection{Possible microbial origin of the n-alkan-2-ones?}

We discard any microbial origin of the $n$-alkan-2-ones from the point of plant collection until analysis because the samples we worked with remained frozen. Moreover, in the Roñanzas record the most abundant $n$-alkan-2-one in almost all the peat samples was $\mathrm{C}_{19}$ (Fig. 2; cf. Ortiz et al., 2010), whereas in most presentday plants the $C_{27}, C_{29}$ and $C_{31}$ homologues are dominant (Table 3 ), except in the fern $P$. aquilinum, whose ketones maximized at $C_{21}$ or $C_{23}$. A similar $n$-alkan-2-one profile to the Roñanzas peat record was found by Lehtonen and Ketola (1990). These authors reported that the $n$-alkan-2-ones maximized at $C_{17}$, with the shorter chain $C_{17}-C_{23}$ homologues greatly increasing in abundance with increasing humification. Furthermore, some bacterial taxa that produce $n$ alkan-2-ones via the metabolism of fatty acids (Lawrence, 1966), fatty alcohols (Hou et al., 1983) and alkanes (Forney and Markovets, 1971), or many fungal taxa, which also produce ketones via an abortive $\beta$-oxidation sequence (Forney and Markovets, 1971), are responsible for the predominance of short chain $\left(C_{19}\right)$ ketones. Thus, the biodegradation of $n$-alkanes is the most plausible explanation for the predominance of the $C_{19}$ ketone throughout the Roñanzas record (cf. Ortiz et al., 2010), especially given that the $\mathrm{C}_{23}$ isomer is the most abundant in most Sphagnum species. In fact, according to Zheng et al. (2007), microbial activity can be considerable in peat, especially during warm and humid episodes. In our view, these processes may occur in the Roñanzas bog, in which

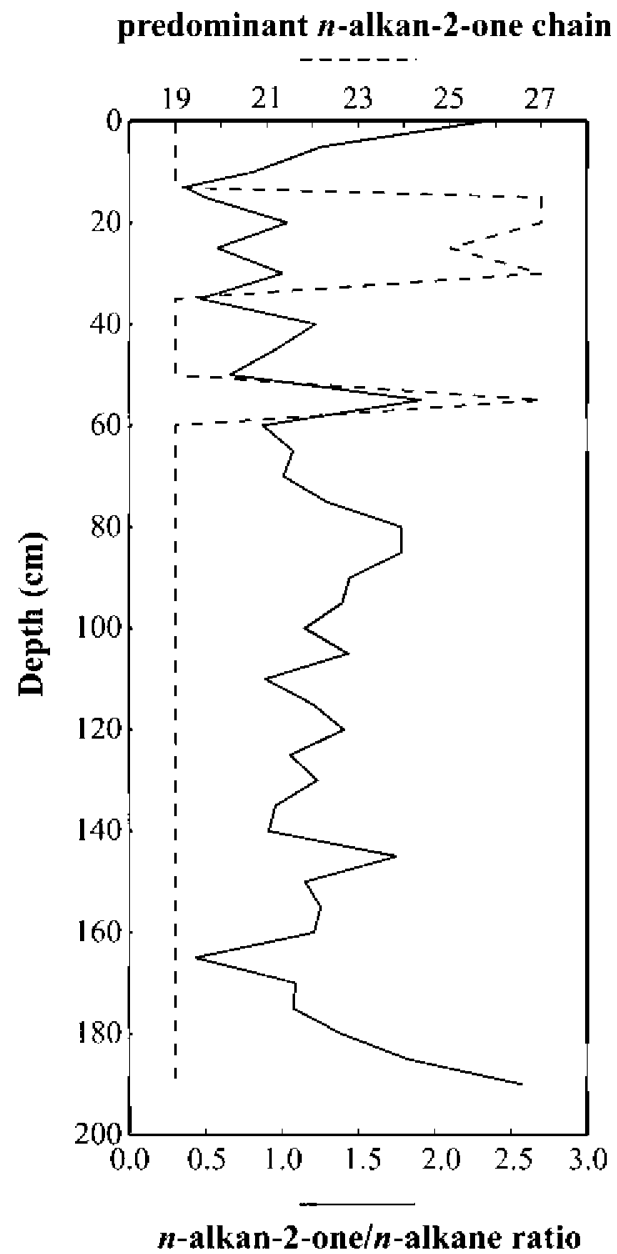

Fig. 2. Predominant $n$-alkan-2-one chain and $n$-alkan-2-one/n-alkane ratio in peat samples along the $2.0-\mathrm{m}$ deep Roñanzas record (cf. Ortiz et al., 2010). desiccation produced during peat extraction during 1970 s and 1980 s would have accelerated biodegradation.

Furthermore, the abundance of $n$-alkan-2-ones in the peat samples from the Roñanzas profile in most cases was higher than the $n$-alkane content, with $n$-alkan-2-one/n-alkane ratio varying between 0.499 and 2.579 (Fig. 2). This observation implies that, in most cases, the presence of $n$-alkan-2-ones was not due only to direct input from plant material but also from the alteration of other organic compounds, probably the oxidation of $n$-alkanes, which is thought to be the only significant pathway for the in situ genesis of longer chain $n$-alkan-2-ones in soils and peat (Amblès et al., 1993; Jaffé et al., 1996; van Bergen et al., 1998).

In this regard, the $n$-alkan-2-one/n-alkane ratio values calculated from concentrations provided by Jansen et al. (2006) and Jansen and Nierop (2009) for present-day plants range between 0.016 and 0.254 , values similar to those found in our study (Table 1). Also, although we cannot calculate this ratio for the Sphagnum specimens studied by Nichols and Huang (2007) because they did not provide the total $n$-alkane concentration (only the abundance of tricosane), the values for total $n$-alkan-2-ones and the $C_{23}$ n-alkane are the same order of magnitude as ours. We wish to highlight that one of the plants (Rhynchospora ruiziana) studied by Jansen and Nierop (2009) contained a similar concentration of $n$-alkan-2-ones in its roots to that of the same genus analysed here, namely Rhynchospora alba, a common specimen of bogs and mires.

However, microbial oxidation can take place in the plant itself especially in the rhizosphere, where roots are accompanied by considerable microbial activity. In fact, such activity may explain why all the samples studied by Jansen and Nierop (2009) containing $n$-alkan-2-ones were mostly roots. This was not our case, as our samples were from leaves and stems. Nevertheless, we also tested the possible in situ microbial contribution to the $n$-alkan-2-ones in the peat-forming plants from Ronanzas, as they appeared in low concentration. Apart from their possible origin as constituents of plants, there would be two major pathways for the presence of $n$-alkan-2-ones, namely $\beta$-oxidation and decarboxylation of $n$-alkanoic acids, and microbially mediated oxidation of $n$-alkanes (Volkman et al., 1983; Chaffee et al., 1986; de Leeuw, 1986; Cranwell et al., 1987; Amblès et al., 1993; Jaffé et al., 1993, 1996; van Bergen et al., 1998; Quénéa et al., 2004).

The oxidative decarboxylation of a certain $n$-alkanoic acids would yield a corresponding $n$-alkan-2-one with one carbon atom fewer, e.g. the degradation of $C_{24}$ alkanoic acid would produce the $\mathrm{C}_{23}$ ketone. The absence of this correspondence between the predominant of $n$-alkan-2-ones and $n$-alkanoic acids in the presentday plants studied here (Table 1) led us to discard the degradation of fatty acids as a significant route for the in situ genesis of ketones. It should be noted that the most abundant ketone has even more carbons than the alkanoic acid in all cases.

In order to determine the possible microbial oxidation of $n$-alkanes that would produce n-alkan-2-ones, we compared their chain length distributions in each sample. In most cases, the ketone profiles appeared not to coincide with the $n$-alkane profiles (Tables 1-3), i.e. four Sphagnum species, Juncus effusus (flowers) and Carex canescens showed a longer chain predominant $n$-alkan-2-one- than the predominant $n$-alkane; in E. mackaiana (leaves and stems), $P$. aquilinum (leaves and stems) and $S$. cuspidatum the most abundant $n$-alkane had four carbons more than the predominant ketone, and C. vulgaris (leaves and stems), C. pyriformis, Molinia caerulea, $R$. alba and $U$. europaeus (leaves) maximized at an $n$-alkane chain with two carbons more than the most abundant $n$-alkan-2-one. For a better appreciation of these findings, Fig. 3 shows the $n$-alkane and $n$-alkan-2-one distributions of representative species of these four clusterings.

In our view, our results indicate that $n$-alkan-2-ones in presentday plants from Roñanzas peat bog are not derived from the 

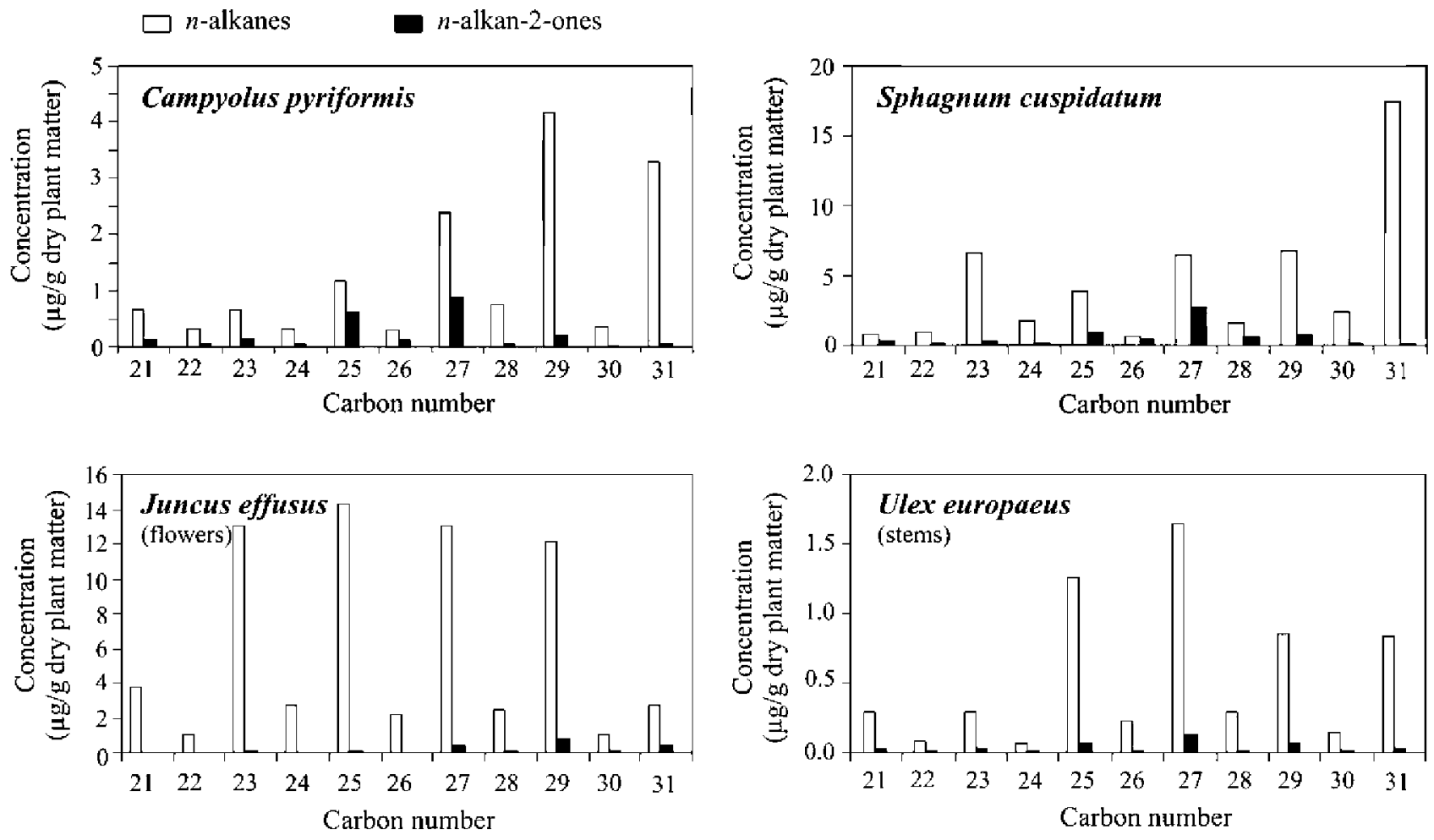

Fig. 3. Distribution of long chain $n$-alkanes and $n$-alkan-2-ones in representative species from the Roñanzas peat bog.

microbial oxidation of $n$-alkanes. Only in six species did the predominant $n$-alkane and $n$-alkan-2-one coincide and we cannot totally discard microbial oxidation in these cases.

Thus, we considered that the concentration and distribution pattern of $n$-alkan-2-ones in the present-day plants studied here were not affected by degradation processes, whereas those from the Roñanzas peat would be derived both from microbial oxidation of the corresponding $n$-alkanes and/or from decarboxylation of the even chain length $n$-alkanoic acids (cf. Arpino et al., 1970; Volkman et al., 1981), as concluded by Ortiz et al. (2010).

\section{Conclusions}

The lipid distributions in present-day peat-forming plants in the Roñanzas bog (northern Spain) reveal the presence of $n$-alkan-2ones in almost all the species analysed, both those belonging to the Sphagnum genus, as well as non-Sphagnum spp., except one fern taxon. In most cases, distributions ranged between $C_{21}$ and $\mathrm{C}_{31}$, with an odd predominance, and maximized at $\mathrm{C}_{27}$ or $\mathrm{C}_{29}$ (Table 3), except for ferns, which maximized at lower $M W\left(C_{21}-C_{23}\right)$. Of note, Sphagnum spp. and Ericaceae species ( $C$. vulgaris and $E$. mackaiana) showed a similar abundance of $n$-alkan-2-ones (Table 3), and higher than in other plant taxa which are commonly used for discriminating between more humid and drier conditions, respectively. However, they cannot be relied on as biomarkers from these plants due to the generally higher production of $n$-alkan-2-ones in sediments through microbial activity. Thus, following Jansen and Nierop (2009), we also conclude that a direct input of $n$-alkan-2-ones from plants is not the dominant contributor to the $n$-alkan-2-one distribution in certain soils and peat bogs.

\section{Acknowledgements}

This research was an Internal Project LEB-3-2007 of the Biomolecular Stratigraphy Laboratory of the Madrid School of Mines. The
Biomolecular Stratigraphy Laboratory is partially funded by ENRESA and the Spanish Geological Survey (Instituto Geológico y Minero de España). We thank two anonymous reviewers for their helpful comments.

\section{Associate Editor-Klaas G.J. Nierop}

\section{References}

Amblès, A., Jambu, P., Jacquesy, J.C., Parlanti, E., Secouet, B., 1993. Changes in the ketone portion of lipidic components during the decomposition of plant debris in a hydromorphic forest-podzol. Soil Science 156, 49-56.

Arpino, P., Albrecht, P., Ourisson, G., 1970. Series homologues aliphatics dans un sediment Eocène d'origen lacustre. Comptes Rendus Academie de Science, Series D 270, 1760-1763.

Avsejs, L.A., Nott, C.J., Xie, S., Maddy, D., Chambers, F.M., Evershed, R.P., 2002. 5-nAlkylresorcinols as biomarkers of sedges in an ombotrophic peat section. Organic Geochemistry 33, 861-867.

Baas, M., Pancost, R., van Geel, B., Sinninghe Damsté, J.S., 2000. A comparative study of lipids in Sphagnum species. Organic Geochemistry 31, 535-541.

Chaffee, A.L., Hoover, D.S., Johns, R.B., Schweighardt, F.K., 1986. Biological markers extractable from coal. In: Johns, R.B. (Ed.), Biological Markers in the Sedimentary Record. Elsevier, Amsterdam, pp. 311-345.

Cranwell, P.A., Eglinton, G., Robinson, N., 1987. Lipids of aquatic organisms as potential constributors to lacustrine sediments - II. Organic Geochemistry 11, 513-527.

de Leeuw, J.W., 1986. Higher-molecular-weight markers. In: Johns, R.B. (Ed.), Biological Markers in the Sedimentary Record. Elsevier, Amsterdam, pp. 249260.

Forney, F.W., Markovets, A.J., 1971. The biology of methyl ketones. Journal of Lipid Research 12, 383-395.

Hernández, M.E., Mead, R., Peralba, M.C., Jaffé, R., 2001. Origin and transport of $n$-alkan-2-ones (sic) in a subtropical estuary: potential biomarkers for seagrassderived organic matter. Organic Geochemistry 32, 21-32.

Hou, C.T., Patel, R., Laskin, A.I., Barnabe, N., Barist, I., 1983. Production of methyl ketones from secondary alcohols by cell suspensions of $C_{2}$ to $C_{4} n$-alkane-grown bacteria. Applied and Environmental Microbiology 46, 178-184.

Jaffé, R., Cabrera, A., Hausmann, K., Carvajal-Chitty, H., 1993. On the origin and fate of $n$-alkane-2-ones in freshwater environments. In: Manning, D. (Ed.), Organic Geochemistry: Applications in Energy and the Natural Environment. Manchester University Press, Manchester, pp. 356-359. 
Jaffé, R., Elisme, T., Cabrera, A.C., 1996. Organic geochemistry of seasonally flooded rain forest soils: molecular composition and early diagenesis of lipid components. Organic Geochemistry 25, 9-17.

Jansen, B., Nierop, K.G.J., 2009. Methyl ketones in high altitude Ecuadorian Andosols confirm excellent conservation of plant-specific $n$-alkane patterns. Organic Geochemistry 40, 61-69.

Jansen, B., Nierop, K.G.J., Hageman, J.A., Cleef, A.M., Verstraten, J.M., 2006. The straight-chain lipid biomarker composition of plant species responsible for the dominant biomass production along two altitudinal transects in the Ecuadorian Andes. Organic Geochemistry 37, 1514-1536.

Lawrence, R.C., 1966. The metabolism of triglycerides by spores of Penicillium roqueforti. Journal of General Microbiology 46, 65-76.

Lehtonen, K., Ketola, M., 1990. Occurrence of long-chain acyclic methyl ketones in Sphagnum and Carex peats of various degrees of humification. Organic Geochemistry $15,275-280$.

Lehtonen, K., Ketola, M., 1993. Solvent-extractable lipids of Sphagnum, Carex Bryales, and Carex-Bryales peats: content and compositional features vs. peat humification. Organic Geochemistry 15, 275-280.

McClymont, E.L. Avsejs, L.A. Nott, C., Roberts, Z.E, Volders, F.D.M., Pancost, R.D. Evershed, R.P., 2005. Reconstructing abrupt climate changes over the European land mass during the late Holocene using biomarker analysis of ombrotrophic peats. In: 22nd International Meeting on Organic Geochemistry, Seville, pp. 173-174 (Abstract)

Morrison, R.I., Bick, W., 1967. The wax fraction of soils: separation and determination of some components. Journal of the Science of Food and Agriculture 18, 351-355.

Nichols, J.E., Huang, Y., 2007. $C_{23}-C_{31}$-alkan-2-ones are biomarkers for the genus Sphagnum in freshwater peatlands. Organic Geochemistry 38, 1972-1976.

Nichols, J.E., Booth, R.K., Jackson, S.T., Pendall, E.G., Hung, Y., 2006. Paleohydrologic reconstruction based on $n$-alkane distributions in ombotrophic peat. Organic Geochemistry $37,1505-1513$.

Nott, C.J., Xie, S., Avsejs, L.A., Maddy, D., Chambers, F.M., Evershed, R.P., 2000. nAlkane distribution in ombotrophic mires as indicators of vegetation change related to climatic variation. Organic Geochemistry 31, 231-235.

Ortiz, J.E., Gallego, J.L.R., Torres, T., Díaz-Bautista, A., Sierra, C., 2010. Palaeoenvironmetal reconstruction of Northern Spain during the last
8000 cal yr BP based on the biomarker content of the Ronanzas peat Bog (Asturias). Organic Geochemistry 41, 454-466.

Pancost, R.D., Baas, M., van Geel, B., Sinninghe Damsté, J.S., 2002. Biomarkers as proxies for plant inputs to peats: an example from a sub-boreal ombotrophic bog. Organic Geochemistry 33, 675-690.

Quénéa, K., Derenne, S., Largeau, C., Rumpel, C., Mariotti, A., 2004. Variation in lipid relative abundance and composition among different particle size fractions of a forest soil. Organic Geochemistry 35, 1355-1370.

van Bergen, P.F., Nott, C.J., Bull, I.D., Poulton, P.R., Evershed, R.P., 1998. Organic geochemical studies of soils from the Rothamsted Classical Experiments - IV Preliminary results from a study of the effect of soil $\mathrm{pH}$ on organic matter decay. Organic Geochemistry 29, 1779-1795.

Volkman, J.K., Smith, D.J., Eglinton, G., Forsberg, T.E.V., Corner, E.D.S., 1981. Stero and fatty acid composition of four marine Haptophycean algae. Journal of the Marine Biological Association 61, 509-527.

Volkman, J.K., Farrington, J.W., Gagosian, R., Wakeham, S.G., 1983. Lipid composition of coastal sediments from the Peru upwelling region. In: Bjorøy, M., Albrecht, P., Cornford, C. (Eds.), Advances in Organic Geochemistry. John Wiley \& Sons, New York, pp. 228-240.

Wenchuan, Q., Dickman, M., Sumin, W., Ruijin, W., Pingzhong, Z., Jianfa, C., 1999 Evidence for an aquatic origin of ketones found in Taihu lake sediments. Hydrobiologia 397, 149-154.

Xie, S., Chen, F., Wang, Zh., Wang, H., Gu, Y., Huang, Y., 2003. Lipid distributions in loess-paleosol sequences from northwest China. Organic Geochemistry 34 $1071-1079$

Xie, S., Nott, C.J., Avsejs, L.A., Maddy, D., Chambers, F.M., Evershed, R.P., 2004 Molecular and isotopic stratigraphy in an ombotrophic mire for paleoclimate reconstruction. Geochimica et Cosmochimica Acta 68, 2849-2862.

Xie, S., Liang, B., Gu, Y.S., Yang, H., 2008. Distributions of $n$-alkan-2-ones in Quaternary paleosols indicative of paleoclimate changes. Acta Palaeontologica Sinica 47, 273-278 (in Chinese with English abstract).

Zheng, Y., Zhou, W., Meyers, P.A., Xie, S., 2007. Lipid biomarkers in the ZoigêHongyuan peat deposit: Indicators of Holocene climate changes in West China. Organic Geochemistry 38, 1927-1940. 